\title{
O ENFRENTAMENTO À MINERAÇÃO EXTRATIVISTA NO QUADRILÁTERO FERRÍFERO DE MINAS GERAIS: CONSIDERAÇÕES SOBRE O SURGIMENTO, CONSTITUIÇÃO E ATUAÇÃO DA FLAMa.
}

\author{
FRENTE A LA MINERÍA EXTRACTIVISTA EN EL FERRIFER QUADRILÁTERO DE \\ MINAS GERAIS: CONSIDERACIONES SOBRE EL SURGIMIENTO, CONSTITUCIÓN Y \\ RENDIMIENTO DE LA FLAMa.
}

\section{FACING THE EXTRATIVIST MINING IN THE FERRIFER QUADRILÁTERO OF MINAS GERAIS: CONSIDERATIONS ABOUT THE FLAMa ARISING, CONSTITUTION AND PERFORMANCE.}

DOI: https://doi.org/10.9771/gmed.v13i2.45074

\begin{abstract}
Kathiuça Bertollo ${ }^{1}$
Resumo: O presente artigo reflete acerca da mineração extrativista no quadrilátero ferrífero de Minas Gerais. Explicita o surgimento, constituição e atuação da FLAMa neste território. Para tanto, reflete sobre o capitalismo enquanto modo de produção fundado a partir da propriedade privada dos meios de produção e do trabalho assalariado, e acerca da sociabilidade decorrente desse processo de exploração, opressão e destruição ambiental. É nesses âmbitos de produção de mercadorias e de reprodução social que a luta de classes é travada, nesta, as lutas sociais protagonizadas pela classe trabalhadora. Nesse sentido, a FLAMa se propõe a ser, e vem se constituindo enquanto instrumento de enfrentamento e tensionamento à sociabilidade burguesa e às violências e violações desencadeadas pelas mineradoras, expoentes do capital nesta singular região.
\end{abstract}

Palavras-chave: Mineração extrativista. Quadrilátero ferrífero. Lutas sociais. FLAMa.

Resumen: Este artículo reflexiona sobre la minería extractiva en el Cuadrángulo de Hierro de Minas Gerais. Explica el surgimiento, constitución y desempeño de FLAMa en este territorio. Por tanto, reflexiona sobre el capitalismo como modo de producción fundado en la propiedad privada de los medios de producción y el trabajo asalariado, y sobre la sociabilidad resultante de este proceso de explotación, opresión y destrucción ambiental. Es en estas esferas de la producción de mercancías y la reproducción social donde se libra la lucha de clases, en la que se desarrollan las luchas sociales que realiza la clase obrera. En este sentido, FLAMa se propone ser y se ha constituido como un instrumento de enfrentamiento y tensión contra la sociabilidad burguesa y la violencia y violaciones desatadas por las empresas mineras, exponentes del capital en esta singular región.

Palabras clave: Minería extractiva. Cuadrilátero del mineral de hierro. Luchas sociales. FLAMa.

Abstract: This article reflects on extractive mining in the Iron Quadrangle of Minas Gerais. It explains the emergence, constitution and performance of FLAMA in this territory. Therefore, it reflects on capitalism as a mode of production founded on private ownership of the means of production and wage labor, and on the sociability resulting from this process of exploitation, oppression and environmental destruction. It is in these spheres of commodity production and social reproduction that the class struggle is waged, in which the social struggles carried out by the working class. In this sense, FLAMa proposes to be and has been constituted as an instrument of confrontation and tension against bourgeois sociability and the violence and violations unleashed by mining companies, exponents of capital in this singular region.

Keywords: Extractive mining. Iron ore quadrilateral. Social struggles. FLAMa. 


\title{
Introdução
}

\author{
Mira mis manos, \\ llenas de hermanos. \\ Que tu sangre cante en el viento \\ como bandera de libertad. \\ (Victor Heredia, letra da música Patria)
}

Este texto se propõe a refletir acerca da mineração extrativista no quadrilátero ferrífero de Minas Gerais e explicita o surgimento, constituição e atuação da Frente Mineira de Luta das Atingidas e Atingidos pela Mineração em Minas Gerais (FLAMa) ao longo do primeiro ano de sua existência. De partida, é importante conceituar o que é a região denominada quadrilátero ferrífero de Minas Gerais. De acordo com Roeser; Roeser (2010, p. 33) é

\begin{abstract}
uma estrutura geológica cuja forma se assemelha a um quadrado, perfaz uma área de aproximadamente $7000 \mathrm{~km}^{2}$ e estende-se entre a antiga capital de Minas Gerais, Ouro Preto a sudeste, e Belo Horizonte, a nova capital a noroeste. É a continuação sul da Serra do Espinhaço. Seu embasamento e áreas circunvizinhas são compostos de gnaisses tonalítico-graníticos de idade arqueana ( $>2.7$ bilhões de anos).
\end{abstract}

Em estudo publicado no ano de 2004 foram evidenciadas as seguintes informações sobre este singular território:

[...] reservas atuais de minério de ferro em aproximadamente 29 bilhões de toneladas. Além de abrigar grandes minerações de ferro, no Quadrilátero Ferrífero também estão presentes empreendimentos minerais de inúmeros outros tipos de rochas e substâncias materiais. Trata-se de uma das mais importantes províncias minerais produtivas do país e a mais conhcida, em termos geológicos. Além das importantes reservas de minério de ferro, o Quadrilátero Ferrífero de Minas Gerais abriga vastas reservas de ouro, calcário, bauxita, manganês, argila, caulim, etc. (PRADO FILHO; SOUZA, 2004, p. 344)

O Quadrilátero Ferrífero de MG é uma área que tem como vértices as cidades de Itabira, a nordeste, Mariana, a sudeste, Congonhas, a sudoeste e Itaúna, a noroeste. (GEOPARK QUADRILÁTERO FERRÍFERO, 2016). Nestes limites, são compreendidos 34 municípios: Barão de Cocais, Belo Horizonte, Belo Vale, Betim, Brumadinho, Caeté, Catas Altas, Congonhas, Conselheiro Lafaiete, Ibirité, Igarapé, Itabira, Itabirito, Itatiaiaçu, Itaúna, Jeceaba, João Monlevade, Mariana, Mário Campos, Mateus Leme, Moeda, Nova Lima, Ouro Branco, Ouro Preto, Raposos, Rio Acima, Rio Manso, Rio Piracicaba, Sabará, Santa Bárbara, Santa Luzia, São Gonçalo do Rio Abaixo, São Joaquim de Bicas, Sarzedo (UFOP, 2021).

Não é apenas esta região que é minerada no estado de Minas Gerais. Há atividade produtiva da mineração e, consequentemente, expressivos impactos ambientais e violências e violações sobre as comunidades em regiões como a Zona da Mata e a região do Serro, dentre outras. O quadrilátero ferrífero é a região que ganha maior relevância, pois ali estão localizados vários municípios considerados muito minerados, tais como: Barão de Cocais, Caeté, Catas Altas, Congonhas, Itabira, Itabirito, Mariana, Nova Lima, Ouro Preto, Rio Piracicaba, Santa Bárbara e São Gonçalo do Rio Abaixo, sendo que o minério de ferro é o principal mineral extraído (BARBOSA; ABREU; SIQUEIRA, 2021, p. 9). 
Este território tão rico, e na mesma proporção, tão explorado e destruído tem em sua história marcas sangrentas e de extrema violência: os rompimentos criminosos de barragens de rejeitos. Segundo Oliveira (2015), aconteceram rompimentos: no ano de 1986 em Itabirito; 2001 em Nova Lima; 2007 em Miraí (atingindo também o município de Muriaé)²; 2014 novamente no município de Itabirito. E no ano de 2015 e 2019 ocorreram os rompimentos criminosos, mundialmente divulgados, devido a proporção dos impactos e mortes causadas, nos municípios de Mariana e Brumadinho, respectivamente.

Esses determinantes naturais e geográficos, e da esfera da produção e reprodução da vida social a partir da mineração extrativista, condicionam e conformam um cenário de exploração da força de trabalho, violências e violações sobre as comunidades e atingidos e atingidas, de destruição ambiental e de mortes.

Nesse sentido, para compreendermos a essência desses fenômenos, assumimos a teoria social crítica e a crítica da economia política para refletirmos sobre o capitalismo enquanto modo de produção fundado a partir da propriedade privada dos meios de produção e do trabalho assalariado, e acerca da sociabilidade decorrente desse processo de exploração, opressão e destruição ambiental. Como síntese, temos que, é nesses âmbitos de produção de mercadorias e de reprodução social que a luta de classes é travada, nesta, as lutas sociais protagonizadas pela classe trabalhadora. A partir dessas formulações com grande poder de abstração, assumimos o percurso teórico, político e analítico da Teoria Marxista da Dependência, para melhor compreendermos as particularidades do capitalismo na América Latina e no quadrilátero ferrífero de Minas Gerais.

Reconhecendo que este território é conformado pela dependência em relação aos países de capitalismo central, e que a superexploração da força de trabalho é o fundamento de tal conformação enquanto capitalismo dependente, e que se explicita no cotidiano e vida dos trabalhadores diretamente vinculados à atividade produtiva da mineração e dos moradores do entorno dos complexos produtivos, temos neste chão um intenso conflito entre as classes sociais antagônicas.

A partir do acirramento no âmbito da esfera produtiva, ou seja, da relação de superexploração da força de trabalho que conforma a relação entre as mineradoras e a classe trabalhadora na região, e que desencadeia intensa e extensa destruição ambiental e os rompimentos criminosos das barragens, por exemplo, os conflitos se ampliam e se espraiam à esfera da reprodução social, uma vez que, perpetuam violências e violações secularmente sofridas pelos homens e mulheres, em sua grande maioria negros e negras descendentes de escravizados.

É no enfrentamento e tensionamento a esta estrutura produtiva e conformação societária que as lutas sociais são travadas nesta singular região de Minas Gerais, do Brasil, da América Latina. As lutas travadas por diferentes sujeitos coletivos neste território, historicamente pautaram o enfrentamento à mineração extrativista e à exploração e destruição que desencadeia. Neste início de século XXI os conflitos e embates entre as mineradoras e as comunidades se agravaram. Tornar-se, de uma hora para outra, um atingido/atingida diretamente, ou estar submetido a situação cotidiana de sofrimento e incerteza 
em função da iminência de novos rompimentos fez com que estes indivíduos se organizassem cada vez mais fortemente e coletivamente construíssem formas de resistência.

Nesse sentido, a FLAMa se propõe a ser, e vem se constituindo enquanto instrumento de enfrentamento e tensionamento à sociabilidade burguesa e às violências e violações desencadeadas pelas mineradoras, expoentes do capital nesta singular região.

\title{
$O$ modo de produção capitalista e a conformação das relações de trabalho nos marcos do capitalismo dependente.
}

\author{
Abre todas las puertas de par en par \\ para que el viento lleve adentro de tu bogar \\ el polen bullicioso de nuestra flor, \\ para que crezcan miles, más de un millón. \\ Camina sobre el hambre, fuerza y valor, \\ que la consigna crezca como el amor \\ y canta con nosotros nuestra canción. \\ Coraje! Coraje! La unión bace la fuerza \\ y un corazón americano crece a la luz del sol. \\ (Victor Heredia, letra da música Ahora, coraje)
}

Para compreendermos acerca da mineração extrativista, sua conformação, impactos e forma de acontecimento na contemporaneidade, especialmente em territórios conformados sob a lógica do capitalismo dependente, caso do quadrilátero ferrífero de Minas Gearias, é fundamental recorrermos à crítica da economia política, às formulações de Marx - especialmente o exposto na clássica obra O Capital, às formulações acerca da particularidade do capitalismo dependente - especialmente as formulações da Teoria Marxista da Dependência, às formulações acerca da relação entre a produção capitalista e a natureza/meio ambiente na América Latina e no território supracitado.

Nesse sentido, assume-se a perspectiva ontológica do gênero humano enquanto ser social e as relações que engendra nos processos de interação entre si e a natureza, e destas interações a partir das diferentes formas de organização societária vivenciadas historicamente, bem como, as possíveis de serem construídas. Assim, o ponto de partida é o entendimento de que

O trabalho é, antes de tudo, um processo entre o homem e a natureza, processo este em que o homem, por sua própria ação, medeia, regula e controla seu metabolismo com a natureza. Ele se confronta com a matéria natural como com uma potência natural [Naturmacht]. A fim de se apropriar da matéria natural de uma forma útil para sua própria vida, ele põe em movimento as forças naturais pertencentes a sua corporeidade: seus braços e pernas, cabeça e mãos. Agindo sobre a natureza externa e modificando-a por meio desse movimento, ele modifica, ao mesmo tempo, sua própria natureza. Ele desenvolve as potências que nela jazem latentes e submete o jogo de suas forças a seu próprio domínio. Não se trata, aqui, das primeiras formas instintivas, animalescas [tierartig], do trabalho. Um incomensurável intervalo de tempo separa o estágio em que o trabalhador se apresenta no mercado como vendedor de sua própria força de trabalho daquele em que o trabalho humano ainda não se desvencilhou de sua forma instintiva. Pressupomos o trabalho numa forma em que ele diz respeito unicamente ao homem (MARX, 2013, p. 255). 
Essa determinação ontológica, própria e eliminável da existência do gênero humano, sob os marcos do capitalismo, modo de produção que atualmente engendra e delineia as relações sociais de produção e de reprodução da vida em sociedade, vai conformar e estar imbricada na chamada lei geral da acumulação capitalista, determinação esta que explicita o caráter antagônico e exploratório de uma classe social sobre outra, uma vez que, o trabalho (relação homem $\mathrm{X}$ natureza) é conformado a partir da propriedade privada dos meios de produção e da condição de assalariamento/exploração da força de trabalho, aspectos e fundamentos estes que condicionam a burguesia enquanto classe que controla o processo produtivo e se apropria da riqueza socialmente produzida e o proletariado enquanto classe explorada na relação de compra e venda da força de trabalho,

portanto, a acumulação de riqueza num polo é, ao mesmo tempo, a acumulação de miséria, o suplício do trabalho, a escravidão, a ignorância, a brutalização e a degradação moral no polo oposto, isto é, do lado da classe que produz seu próprio produto como capital (MARX, 2013, p. 721).

Demarca-se, portanto, a partir das formulações de Lenin (1961, p.128 apud OSÓRIO, 2014, p. 116) que

Chamam-se classes a grandes grupos de pessoas que se diferenciam entre si pelo seu lugar num sistema de produção social historicamente determinado, pela sua relação (as mais das vezes fixada e formulada nas leis) com os meios de produção, pelo seu papel na organização social do trabalho e, consequentemente, pelo modo de obtenção e pelas dimensões da parte da riqueza social de que dispõem.

A partir de tais considerações e reconhecendo a particularidade do continente Latino-americano, território submetido por séculos ao saqueio, à violência e à exploração enquanto colônia de Portugal, território que mesmo após a sua independência formal permanece submetido a tais condições, uma vez que neste chão é a lógica do capitalismo dependente e subordinado aos centros imperialistas que vigora e ordena as relações de produção e de reprodução social, é extremamente válida a afirmação de Marx em diálogo crítico com as formulações de E. G. Wakefield, quando nos diz que " ele descobriu que o capital não é uma coisa, mas uma relação social entre pessoas, intermediada por coisas” (MARX, 2013, p. 836).

É essa relação social que vai configurando o trabalho e a forma de utilização da força de trabalho, consequentemente, vai conformando as classes sociais, o contexto da luta de classes e no caso em tela, a atividade da mineração extrativista.

Tais compreensões nos remetem à outra elaboração relevante da obra marxiana, o processo de acumulação primitiva. Compreendemos que este processo demarca historicamente não somente os primórdios do capitalismo na Europa, nos países hoje reconhecidos como de capitalismo central, mas também demarca e conforma o lugar e o papel desempenhado pela África e América Latina nesse processo embrionário de constituição do modo de produção capitalista abarcando as mais variadas regiões do globo.

A descoberta das terras auríferas e argentíferas na América, o extermínio, a escravização e o soterramento da população nativa nas minas, o começo da conquista e saqueio das Índias Orientais, a transformação da África numa reserva para a caça comercial de peles-negras caracterizam a aurora da era da produção capitalista (MARX, 2013, p. 821). 
É relevante destacar que a violência e as violações, bases de tais processos históricos perpetuamse ao longo do tempo e se fazem constantes nos processos de conformação do capitalismo no globo. Nesse sentido, a América Latina, território que se configurará a partir de um "capitalismo sui generis, que só adquire sentido se o contemplarmos na perspectiva do sistema em seu conjunto, tanto em nível nacional, quanto, e principalmente, em nível internacional” (MARINI, 2005, p. 138), é solo fértil das mais variadas formas e expressões violentas de tais processos econômico-produtivos.

Forjada no calor da expansão comercial promovida no século 16 pelo capitalismo nascente, a América Latina se desenvolve em estreita consonância com a dinâmica do capitalismo internacional. Colônia produtora de metais preciosos e gêneros exóticos, a América Latina contribuiu em um primeiro momento com o aumento do fluxo de mercadorias e a expansão dos meios de pagamento, que, ao mesmo tempo em que permitiam o desenvolvimento do capital comercial e bancário na Europa, sustentaram o sistema manufatureiro europeu e propiciaram o caminho para a criação da grande indústria (MARINI, 2005, p. 140).

Prossegue o autor afirmando que o marco histórico, econômico e político da revolução industrial, coincide temporalmente com a conquista da independência política na América Latina, primeiras décadas do século 19. Tal contexto, se conformará a partir da relação de um conjunto de países com a Inglaterra e terá como base o fluxo de mercadorias e posteriormente de capitais, em que

Ignorando uns aos outros, os novos países se articularão diretamente com a metrópole inglesa e, em função dos requerimentos desta, começarão a produzir e a exportar bens primários, em troca de manufaturas de consumo e- quando a exportação supera as importações- de dívidas. É a partir desse momento que as relações da América Latina com os centros capitalistas europeus se inserem em uma estrutura definida: a divisão internacional do trabalho, que determinará o sentido do desenvolvimento posterior da região (MARINI, 2005, p. 140 e 141).

A partir das relações entre ex-colônias, agora Estados-Nação formalmente independentes e centros industriais europeus o capitalismo, enquanto modo de produção, vai se expandindo e se enraizando em todos os territórios do globo a partir da divisão internacional do trabalho. Tal contexto econômico-político é que configurará

a dependência, entendida como uma relação de subordinação entre nações formalmente independentes, em cujo marco as relações de produção das nações subordinadas são modificadas ou recriadas para assegurar a reprodução ampliada da dependência. A consequência da dependência não pode ser, portanto, nada mais do que maior dependência, e sua superação supõe necessariamente a supressão das relações de produção nela envolvidas (MARINI, 2005, p. 141).

O mesmo autor prossegue suas formulações e explicita em relação à industrialização europeia ocorrida a partir do século XIX, que a função cumprida pela América Latina no desenvolvimento do capitalismo dá-se fundamentalmente por dois aspectos: a oferta de gêneros alimentícios e de matériasprimas industriais. Também, demarca o importante fato de que

[...] a participação da América Latina no mercado mundial contribuirá para que o eixo da acumulação na economia industrial se desloque da produção de mais-valia absoluta para a de mais-valia relativa, ou seja, que a acumulação passe a depender mais do aumento da capacidade produtiva do trabalho do que simplesmente da exploração do trabalhador. No entanto, o desenvolvimento da produção latino-americana, que permite à região coadjuvar com essa mudança qualitativa nos países centrais, dar-se-á 
fundamentalmente com base em uma maior exploração do trabalhador (MARINI, 2005, p. 144)

É a partir das trocas comerciais entre Estados-Nação que ocupam distintas posições acerca do estágio de desenvolvimento do modo de produção em seus territórios, e da troca de distintas mercadorias, manufaturas e matérias-primas, que se configurará a chamada troca desigual. Nas palavras de Marini (2005 p. 154)

[...] no marco dessa troca, a apropriação de valor realizado encobre a apropriação de uma mais-valia que é gerada mediante a exploração do trabalho no interior de cada nação. [...] o problema colocado pela troca desigual para a américa Latina não é precisamente o de se contrapor à transferência de valor que implica, mas compensar a perda de mais-valia, e que, incapaz de impedi-la no nível das relações de mercado, a reação da economia dependente é compensá-la no plano da produção interna.

As formulações do autor remetem ao entendimento de que a superexploração da força de trabalho é o fundamento da dependência, e acontece a partir de três mecanismos: “a intensificação do trabalho, a prolongação da jornada de trabalho e a expropriação de parte do trabalho necessário ao operário para repor sua força de trabalho” (MARINI, 2005, p. 156).

Prosseguindo suas formulações, o autor apresenta uma reflexão que é de relevância para compreendermos acerca da requisição da força de trabalho e da relação homem X natureza no contexto da atividade produtiva da mineração extrativista sob os marcos do capitalismo dependente. Afirma que

[...] um modo de produção fundado exclusivamente na maior exploração do trabalhador, e não no desenvolvimento de sua capacidade produtiva. Isto é condizente com o baixo nível de desenvolvimento das forças produtivas nas economia latinoamericana, mas também com os tipos de atividades que ali se realizam. De fato, mais que na indústria fabril, na qual um aumento de trabalho implica pelo menos um maior gasto de matérias-primas, na indústria extrativa e na agricultura o efeito do aumento do trabalho sobre os elementos do capital constante são muito menos sensíveis, sendo possível, pela simples ação do homem sobre a natureza aumentar a riqueza produzida sem um capital adicional. Entende-se que nessas circunstâncias, a atividade produtiva baseia-se sobretudo no uso extensivo e intensivo da força de trabalho: isso permite baixar a composição-valor do capital, o que, aliado à intensificação do grau de exploração do trabalho, faz com que se elevem simultaneamente as taxas de mais valia e de lucro (MARINI, 2005, p. 156).

A partir dessas considerações e direcionando a reflexão à atividade produtiva da mineração extrativista, pode-se afirmar que este contexto na região do quadrilátero ferrífero assenta-se na lógica da dependência e tem como fundamento a superexploração da força de trabalho nos termos do processo de produção de valor, desencadeando junto aos trabalhadores um conjunto de misérias, privações e violências (BERTOLLO, 2017). Como evidência empírica desta realidade podemos citar as concessões governamentais para a realização da mineração. No Brasil, conforme dados emitidos pelo Ministério das Minas e Energia, mais precisamente do Plano nacional de Mineração 2030, dados estes, citados por ESPINOZA (2018a, p. 39) temos que “en Brasil las concesiones mineras pasaron de 142 en 1999 a 404 en el 2009, es decir, un aumento de casi 300\% en un periodo de 10 años”.

Outra evidência empírica desse contexto de dependência e superexploração da força de trabalho são os rompimentos/crimes de barragens de rejeitos das mineradoras. O rompimento/crime da barragem de Fundão, de propriedade das mineradoras Samarco, Vale e BHP Billiton, ocorrido no dia 05 de 
novembro de 2015 em Mariana-MG e o rompimento da barragem do Córrego do Feijão, de propriedade da mineradora Vale, ocorrido no dia 25 de janeiro de 2019 em Brumadinho-MG, além de desencadear a morte de rios, lençóis freáticos, da fauna e flora por extensão de milhares de quilômetros ao longo do lastro de lama e rejeitos tóxicos que as barragens despejaram no meio ambiente, desencadearam a morte imediata de trabalhadores e de moradores das comunidades/distritos do entorno das barragens, que foram completamente destruídos. Destaca-se que o rompimento/crime da barragem de Fundão ceifou a vida de 20 pessoas, destas, 14 eram trabalhadores que estavam no canteiro de obras, sendo que 12 eram terceirizados (XAVIER; VIEIRA, 2016), (ZONTA, 2016), já o rompimento crime da barragem do Córrego do Feijão ceifou imediatamente a vida de cerca de 300 trabalhadores que estavam no canteiro de obras e no restaurante da mineradora, sendo considerado o maior acidente de trabalho com perdas de vidas humanas do país (BERTOLLO, NOGUEIRA, 2020).

Além disso, é fundamental citar a questão dos turnos laborais como expressão da superexploração da força de trabalho, uma vez que tal forma de organização laboral tem incidência direta na qualidade e condição de saúde dos trabalhadores. No âmbito das relações laborais e organizativa enquanto classe, a constante troca de turnos dos trabalhadores dificulta a própria organização enquanto categoria, dificulta o reconhecimento e a aproximação entre colegas de trabalho que possuem as mesmas demandas e reclamações em relação às condições de trabalho nas mineradoras, o que vai enfraquecendo a organização coletiva e sindical destes. Também, é fundamental mencionar que o trabalho em turnos contribui para afastar o trabalhador das relações sociais e comunitárias uma vez que lhe é negada a possibilidade de estar presente constantemente na rotina doméstica e no convívio familiar, lhe é negado o sono regrado, os momentos de lazer, de acompanhamento do crescimento dos filhos e a interação com a comunidade, seja em atividades como o acesso à educação, eventos culturais, religiosos, etc.; isso tudo, dentre outros aspectos desencadeados pelo trabalho em turnos, tem influência direta no encurtamento da vida biológica, subjetiva e social do conjunto de trabalhadores vinculados a essa atividade produtiva (BERTOLLO, 2017).

Também, é fundamental mencionar que expressivamente as relações de trabalho na mineração extrativista na região do quadrilátero ferrífero de Minas Gerais se dão a partir da terceirização. Esse contexto tem profundas modificações a partir da década de 1990, período histórico marcado por profundas regressões nas conquistas históricas da classe trabalhadora, nos processos produtivos e na relação do Estado com a sociedade, uma vez que, a reestruturação produtiva e o ideário neoliberal vão se enraizando e ganhando espaço no território brasileiro, o que reafirma a condição de dependência e superexploração da força de trabalho. Nesse contexto, a privatização da Companhia Vale do Rio Doce, que de empresa público-estatal passa a ter diferentes formas de vinculação do seu quadro laboral, e o fato de outras mineradoras também assumirem a terceirização como forma contratual para a condução de parte expressiva de seus processos produtivos, principalmente de atividades que se referem ao canteiro de obras, ao setor de alimentação-refeitórios, etc. vão desencadeando perdas ao que se refere à garantia de 
direitos já adquiridos pelas categorias diretamente vinculadas a essa atividade produtiva, bem como à classe trabalhadora em seu conjunto.

Destaca-se que uma das principais questões que incidem de forma negativa sobre os trabalhadores a partir da privatização da Companhia Vale do Rio Doce e da terceirização, que vai se tornando algo rotineiro nos processos produtivos das mineradoras, é a questão da redução salarial. Em aula conjunta realizada pelas disciplinas de 'Trabalho e Sociabilidade' e 'Classes e Movimentos Sociais' do curso de Serviço Social da Universidade Federal de Ouro Preto, realizada no dia 23 de março de 2021, o dirigente sindical Bruno Teixeira ministrou uma palestra e afirmou que

Antes da privatização em 1997, o salário base na Vale era de 11 salários-mínimos, hoje o salário base de um trabalhador na Vale é em torno de $\mathrm{R} \$ 1600,00$ a $\mathrm{R} \$ 1.700,00$. [...] Em 2015, um trabalhador Vale trabalhava em torno de 1 hora e 15 minutos dentro de uma jornada de 8 horas de trabalho, em 1 hora e 15 minutos o trabalhador pagava o seu salário, o restante era lucratividade para empresa. Já em 2018, a Vale conseguiu reduzir esse tempo, a partir da retirada de direitos, para 51 minutos em uma jornada de 8 horas (TEIXEIRA, 2021).

Alinhado às formulações da Teoria Marxista da Dependência, Osório (2009, p. 177, grifo do autor) destaca que "um salário insuficiente ou um processo de trabalho com superdesgaste [...] que encurte o tempo de vida útil total e de vida total" isto é, "casos no qual o capital está se apropriando hoje dos anos futuros de trabalho e de vida" são "processos de superexploração, na medida em que se viola o valor da força de trabalho". Tal situação se explicita no cotidiano e vida e nas relações laborais dos trabalhadores vinculados à atividade produtiva da mineração extrativista no quadrilátero ferrífero de Minas Gerais, uma vez que, este contexto laboral é fundado em intensas e extenuantes jornadas de trabalho, no pagamento de baixos salários, na precarização e desmonte dos direitos trabalhistas e previdenciários historicamente conquistados e culmina historicamente em inúmeros casos de rompimentos criminosos de barragens de rejeitos, sendo os ocorridos em 2015 e 2019 os mais conhecidos devido à proporção da destruição e número de mortes causadas.

Ao explicitar, mesmo que brevemente as considerações acima, objetivamos demarcar que a relação homem X natureza, ou seja, o trabalho, atividade própria do ser humano e eliminável de sua existência, é condicionado e direcionado, a partir da forma capitalista de produção (propriedade privada dos meios de produção e exploração da força de trabalho), para a produção de mercadorias e tal determinação é a que ocorre e estrutura a atividade da mineração extrativista. Nesse sentido, a formamercadoria

[...] reflete aos homens os caracteres sociais de seu próprio trabalho como caracteres objetivos dos próprios produtos do trabalho, como propriedades sociais que são naturais a essas coisas e, por isso, reflete também a relação social dos produtores com o trabalho total como uma relação social entre os objetos, existente à margem dos produtores (MARX, 2013, p. 147).

São estas relações sociais que conformam estruturalmente o embate entre as classes sociais fundamentais nessa singular região do país e abrem espaço às lutas e resistências travadas pela classe trabalhadora e seus diversos sujeitos coletivos atuantes na região. 


\section{Luta de classes e as lutas sociais travadas no enfrentamento à mineração extrativista na América} Latina e no quadrilátero ferrífero de Minas Gerais.

Volveremos a soñar; nosotros somos parte de un sueño.

Volveremos a cantar, sobrevivientes de tanto infierno. Todo un pueblo soñará, todo un pueblo cantará.

La sonrisa de los que sueñan hará un camino hasta la verdad. (Victor Heredia, letra da música Patria)

As formulações marxianas, a partir do materialismo histórico-dialético, permitem o entendimento das relações de produção capitalistas e da sociabilidade por elas engendradas. Tal método de interpretação e intervenção na realidade decifra e desmistifica a aparência natural das relações fundadas a partir da dominação e exploração de uma classe social (burguesia) sobre outra (proletariado) e das relações sociais a partir dessa premissa, cujo complexo fundante é o trabalho.

Mattos, (2019, p. 44) afirma que "Marx integrou em sua análise vida material e subjetividade por meio da determinação de um conceito mais amplo, que remete ao seu objetivo de entendimento totalizante do social, o modo de produção". Prossegue, explicitando uma formulação em que o filósofo alemão nos diz que "o modo de produção da vida material condiciona o desenvolvimento da vida social, política e intelectual em geral. Não é a consciência dos homens que determina o seu ser; é o seu ser social que, inversamente, determina a sua consciência” Marx (1977, p. 24 apud MATTOS, 2019, p. 44).

Esta formulação nos remete a outra clássica afirmação de Marx explicitada nos primeiros parágrafos da obra $O 18$ de brumário de Luís Bonaparte, obra escrita entre dezembro de 1851 e janeiro de 1852, em que o filósofo apreende e analisa as principais tendências que estavam presentes no contexto revolucionário de 1848 e antirrevolucionário posteriormente estabelecido na França a partir das posições assumidas pelas classes sociais e da conformação e papel desempenhado pelo Estado em tal contexto histórico, econômico, político e social. Marx (2011, p.25) nos diz: “Os homens fazem a sua própria história; contudo, não a fazem de livre e espontânea vontade, pois não são eles quem escolhem as circunstâncias sob as quais ela é feita, mas estas lhes foram transmitidas assim como se encontram".

Nessa esteira teórica Mattos (2019, p. 45) afirma

[...] a ideia de determinação [material] tem relação com o que é prévio na práxis humana, bem como com os limites e as pressões que atuam sobre a subjetividade humana no interior mesmo dessa práxis social. Os limites impostos pela determinação do ser social, por sua vez, condicionam a capacidade de apreensão da realidade pelos homens e, portanto, de sua intervenção sobre ela (seu potencial como sujeitos da história).

Acerca das classes sociais e do processo de tomada de consciência da sua condição de classe para si, Osório (2014, p. 131- 132) afirma 
Independentemente de que as classes sociais reconheçam as relações sociais em que se encontram inseridas e que as constituem como agrupamentos humanos diferenciados, essas relações sociais existem, operam e determinam as classes sociais. [...] quando esses agrupamentos humanos se reconhecem a si mesmos, reconhecem seu lugar na sociedade, seus interesses particulares, e reconhecem, por sua vez, os demais agrupamentos classistas, seus interesses, e as classes com as quais mantêm posições e interesses em conflito e antagonismo, então se fazem classes sociais que são agora classes para si.

Posto que a burguesia e o proletariado se constituem nas classes sociais fundamentais da sociedade forjada a partir do modo de produção capitalista, temos que o antagonismo e os embates, isto é, o contexto da luta de classes se põe nos mais variados âmbitos da vida social, e consequentemente se explicita no contexto da mineração extrativista na América Latina, no quadrilátero ferrífero de Minas Gerais.

O saqueio dos chamados bens naturais comuns e a exploração da força de trabalho a níveis extremos é secular na América Latina. Em cada país, esses processos violentos assumem contornos específicos e dramáticos a partir das suas particularidades, no entanto, o que demarca a história do continente como um todo é que seu território foi colônia de países europeus, países que posteriormente vão se configurar em grandes potências imperialistas e perpetuarão o contexto de exploração da natureza e de superexploração da força de trabalho neste chão de Estados-Nação formalmente independentes. SEONAE; ALGRANATI (2013, p.69) afirmam que "el modelo extractivo exportador se profundizó em estas regiones a sangre y fuego".

Conforme RRI (2013, p. 40 apud ESPINOZA, 2018a, p. 31-38) a

América Latina cuenta con inmensos activos de recursos naturales no renovables: posee un $13 \%$ de las reservas de petróleo del planeta, $65 \%$ del litio, $49 \%$ de la plata, $44 \%$ del cobre, $33 \%$ del estaño, $32 \%$ del molibdeno, $26 \%$ de la bauxita, $23 \%$ del níquel, $22 \%$ del hierro y $22 \%$ del zinc. De acuerdo con las tendencias marcadas por la década 2000 2010, 13 países de la región están entre los 15 mayores productores de materias primas minerales del mundo".

O ‘trágico destino' deste singular território tão rico e tão explorado é também retratado na célebre obra literária/jornalística/política As veias abertas da América Latina.

Há dois lados na divisão internacional do trabalho: um em que alguns países especializam-se em ganhar, e outro em que se especializaram em perder. Nossa comarca do mundo, que hoje chamamos de América Latina, foi precoce: especializou-se em perder desde os remotos tempos em que os europeus do Renascimento se abalançaram pelo mar e fincaram os dentes em sua garganta. Passaram os séculos, e a América Latina aperfeiçoou suas funções. Este já não é o reino das maravilhas, onde a realidade derrotava a fábula e a imaginação era humilhada pelos troféus das conquistas, as jazidas de ouro e as montanhas de prata. Mas a região continua trabalhando como um serviçal. Continua existindo a serviço de necessidades alheias, como fonte e reserva de petróleo e ferro, cobre e carne, frutas e café, matérias-primas e alimentos, destinados aos países ricos que ganham, consumindo-os, muito mais do que a América Latina ganha produzindo-os GALEANO (2004, p. 13).

A partir do registro realizado por Eduardo Galeano (2004), dando ênfase a Potosí (Bolívia), Zacatecas (México) e Ouro Preto (Brasil) temos o retrato do que foi (e do que permanece sendo) a América Latina, continente marcado a sangue e fogo, saqueado e explorado em seu chão, seus bens naturais comuns e em suas gentes. Nessa esteira, ESPINOZA (2018a) afirma que o número de toneladas 
de metais extraídos na América Latina aumentou quatro vezes no período compreendido entre 1978-2008, o que tornou esta a região que recebeu os maiores fluxos de investimento em mineração no mundo. A partir de Hernández Morales (2014, p. 50-51 apud ESPINOZA, 2018a, p. 38) temos a informação de que "el capital minero transnacional proviene principalmente de Canadá, China, Estados Unidos, Japón, Corea del Sur, Australia, Inglaterra y Sudáfrica".

Nesse sentido histórico e econômico, a condição do Brasil é emblemática, mais emblemática ainda é a região do quadrilátero ferrífero de Minas Gerais, uma vez que, comporta territórios hoje reconhecidos como municípios de Mariana e Ouro Preto, estes, marcados secularmente pela escravização do povo negro e pela atividade da mineração de ouro no passado colonial, e atualmente, sob os marcos da mundialização do capital, pela mineração extrativista de minério de ferro, dentre outros minérios e minerais.

Coelho et al. (2020, p. 103-104) afirmam que "Uma máquina de moer gente foi a marca da exploração nas primeiras regiões mineradas no Brasil". Prosseguem afirmando que "quando olhamos a história da mineração no Brasil da época colonial até os dias de hoje temos inúmeros episódios de genocídios, destruição ambiental, domínio à força dos territórios e dos habitantes que neles residiam e repressão à organização dos trabalhadores da mineração" (COELHO et al., 2020, p. 104).

São processos extremamente violentos que delineiam a relação homem $\mathrm{X}$ natureza no continente latino-americano. A violência utilizada para destruir e se apropriar dos bens naturais comuns, bem como, para explorar a força de trabalho e matar a vida humana é, pelos povos e etnias então escravizados, e pelos, posteriormente, trabalhadores livres/assalariados enfrentada com força, consciência e posição de classe, isto é, dá-se através de tensionamentos, seja por melhoras imediatas e políticas, mas também, assume a perspectiva de superação dessa limitadora condição de pré-bistória da bumanidade, tal qual como Marx definiu o tempo histórico e sociabilidade conformados pelo e a partir do modo de produção capitalista.

É relevante mencionar que, ao passo que o capitalismo vai se conformando e assumindo novas nuances e contornos ao que se refere à esfera da produção de mercadorias, isto é, dá-se a partir da relação entre países imperialistas e países de capitalismo dependente, a partir da condição da superexploração da força de trabalho, da mundialização do capital, de processos cada vez mais violentos e de expropriação e desposseção de territórios e comunidades e a partir do desmonte das conquistas e dos direitos trabalhistas e sociais historicamente conquistados, dentre outros aspectos, a luta e a resistência dos povos também se explicita e se amplia.

Assim, acerca da atividade produtiva da mineração extrativista, é possível afirmar que "no obstante, casi como una regla del poder, a cada tentativa de hegemonía suele contraponérsele al menos un acto de impugnación. Y en América Latina es factible hallar un múltiple y extendido repertorio de acción colectiva que ha refutado y hasta repelido al extractivismo minero" (ESPINOZA, 2018b, p. 54).

O mesmo autor evidencia que são variadas as formas que os indivíduos e grupos antiextrativistas utilizam-se para fazer frente, denunciar e impedir o avanço da mineração extrativista, 
consequentemente da destruição ambiental sobre os bens naturais comuns no continente. Dentre os quais se destacam: marchas, assembleias, seminários, fóruns, palestras, fechamento de estradas, greves de fome, consultas populares/comunitárias, referendos e propostas de novas legislações (ESPINOZA, 2018b).

A articulação e o caráter internacionalista das lutas são elementos fundamentais. Destacamos a Articulação Internacional dos Atingidos e Atingidas pela V ale como um exemplo dessa forma organizativa.

A Articulação Internacional dos Atingidos pela Vale é uma rede autônoma e plural que busca possibilidade de avançar na luta por direitos em todos os países com atuação da empresa Vale S.A. Somos um amplo grupo de organizações, movimentos sociais e sindicais do Brasil, Argentina, Chile, Peru, Canadá, Moçambique. Nosso objetivo é contribuir para o fortalecimento dessas comunidades em rede, promovendo estratégias de enfrentamento aos impactos socioambientais relacionados à indústria extrativa da mineração. O fazer dessa luta utiliza o enfrentamento direto e as ações institucionais; desde as mobilizações na Estrada de Ferro de Carajás, ocupações, até a participação nas assembleias de acionistas da empresa Vale (ARTICULAÇÃO INTERNACIONAL DOS ATINGIDOS PELA VALE, 2021).

Direcionando a análise para os enfrentamentos travados na região do quadrilátero ferrífero temos a relevante atuação de movimentos sociais, de entidades sindicais, dos comitês e das associações dos atingidos diretamente pelas violências e violações no contexto da mineração extrativista, dentre os quais, evidenciamos: o Movimento pela Soberania Popular na Mineração (MAM), o Movimento dos Atingidos por Barragens (MAB), o Sindicato Metabase Inconfidentes, o Comitê Popular dos Atingidos pela Mineração em Itabira e Região e a Comissão dos Atingidos de Antônio Pereira. Estes sujeitos coletivos, dentre outros, explicitam os contornos exploratórios que a atividade produtiva da mineração assume e os impactos decorrentes dessa forma de apropriação e destruição da natureza e da exploração da força de trabalho para a produção de mercadorias.

Ressalta-se que após o rompimento/crime de 05 de novembro de 2015 as lutas se intensificaram, no entanto, as resistências travadas na região contra os desmandos das mineradoras é histórico. Segundo Carvalho (2013) no ano de 2009 ocorreram expressivas mobilizações puxadas pelo Sindicato Metabase Itabira e pelo Sindicatos Metabase Incofidentes, sendo que cerca de 15 mil pessoas foram às ruas de Itabira-MG e cerca de 12 mil às ruas de Mariana-MG protestar contra as demissões em massa na Vale.

Em relação ao MAM e ao MAB é relevante mencionar que a atuação destes movimentos sociais no estado de Minas Gerais e na região do quadrilátero ferrífero precede o rompimento/crime de 2015. Após a ocorrência deste, as ações se intensificam e se ampliam, uma vez que a comunidade atingida direta e indiretamente passa a se organizar mais fortemente e a compor estes movimentos, bem como, estes movimentos passam a subsidiar e fortalecer essa articulação popular-comunitária.

Após 2015, também se destaca o fato de que as comunidades dos entornos dos complexos produtivos e das barragens passaram a ter maior noção do perigo cotidiano a que estão submetidos. Passaram a questionar mais fortemente a atuação das mineradoras e reivindicar equipes de assessoria técnica, dados e informações oficiais sobre a condição das estruturas das barragens, indenizações pelas remoções forçadas e pela mudança nos modos de vida e de obtenção de renda, dentre outros aspectos. 
Destaca-se que tais reivindicações não correm de modo tranquilo e ágil, pelo contrário, são perpassadas por morosidade do sistema judiciário, morosidade e posicionamentos, por vezes, questionáveis de instâncias como a defesa civil, secretarias municipais e estadual de meio ambiente, dentre outras.

Nesse sentido, o contexto da luta de classes é vivenciado e perpassa o cotidiano e vida dos trabalhadores e trabalhadoras e dos atingidos e atingidas pela mineração extrativista na região. Temos o cenário composto de um lado, pela classe dominante, os expoentes do capital, neste caso, as mineradoras, e de outro lado, a classe trabalhadora, os homens e mulheres que dependem da venda da sua força de trabalho nesta atividade produtiva, e que são aqueles e aquelas que residem nos territórios em risco devido à proximidade com os complexos produtivos. Também, a presença do Estado e de seus âmbitos de gestão e do judiciário é uma constante, seja para garantir alguns direitos, ressalta-se, somente após muita luta e resistência dos atingidos e atingidas, seja, no desenrolar extremamente moroso e burocrático dos trâmites legais e normativos e que, por vezes, é favorável às mineradoras e contrário às legítimas demandas e requisições apresentadas pelas comunidades atingidas.

Ainda, acerca do Estado no contexto da mineração extrativista é relevante mencionar que o avanço da mineração transnacional na América Latina ocorre amparado e legitimado institucionalmente pelos governos da região. Conforme ESPINOZA (2018a) desde a década de 1990, 15 países do continente promulgaram novas ou reformularam as legislações acerca da mineração em seus territórios. Todas estas legislações e normativas governamentais assumem o sentido de garantir às mineradoras simplificações administrativas e vantagens fiscais. No Brasil, tais modificações ocorreram em 1996, 2015 e mais recentemente, nos governos Temer e Bolsonaro, o país também vivenciou retrocessos legais ao que se refere à forma de ocorrência da mineração no país.

Diante de tal cenário, é relevante recorrermos e reivindicarmos a clássica obra Manifesto Comunista, quando os autores, após uma precisa análise, em nível geral e abstrato, da constituição e conformação da sociedade burguesa, das suas contradições e antagonismos entre as classes sociais fundamentais, burguesia e proletariado, nos dizem que "com o estabelecimento da grande indústria e do mercado mundial a burguesia conquistou, finalmente, o domínio político exclusivo no Estado representativo moderno. O poder do Estado moderno não passa de um comitê que administra os negócios comuns da classe burguesa como um todo” (MARX; ENGELS, 2008, p. 13-14).

Nessa esteira teórica, podemos afirmar que a história é construída e constituída nos marcos da luta de classes. No capitalismo, os avanços e retrocessos de uma classe social fundamental implicam na existência e conformação de outra classe social fundamental. Nesse contexto, dizem Marx; Engels (2008) que os proletários não têm nada a perder além de seus grilhões.

A América Latina enquanto território historicamente saqueado e explorado, tem uma vasta multiplicidade de lutas e resistências travadas pelo seu povo, pela classe trabalhadora. Os movimentos revolucionários, as lutas de libertação nacional, as lutas e a experiência revolucionária cubana, as lutas estudantis-juvenis, as lutas em defesa e travadas pelos povos originários, as lutas em defesa do meio ambiente e dos bens naturais comuns são exemplos dos tensionamentos travados secularmente neste 
chão. É nessa esteira que os sujeitos coletivos, que a classe trabalhadora, que as e os historicamente explorados e oprimidos da região do quadrilátero ferrífero de Minas Gerais se inscrevem e fazem a história do gênero humano a partir de tensionamentos à ordem hegemônica do capital e no sentido de construção de outro modo de produzir e reproduzir a vida social.

\section{A Frente Mineira de Luta das Atingidas e Atingidos pela Mineração em Minas Gerais - FLAMA: apontamentos sobre o seu surgimento, configuração e atuação.}

Por América resisto. Por América me muero. Por América, mi vida me arrancará el extranjero. El español que me mata no sabe que está cortando la cabeza que mañana cantará en un canto eterno.

(Victor Heredia, letra da música Muerte de Túpac Amaru)

A Frente Mineira de Luta dos Atingidos e Atingidas pela mineração em Minas Gerais (FLAMa) ${ }^{3}$ é uma articulação relativamente recente, que surge e se alimenta das lutas e resistências historicamente travadas por diferentes sujeitos coletivos e pela classe trabalhadora em seu conjunto ao contexto da mineração extrativista, especialmente na região do quadrilátero ferrífero de Minas Gerais. Em 14 de maio de 2020 ocorreu a primeira reunião com a presença de diversas entidades sindicais, movimentos sociais, organizações da igreja católica, atingidos e atingidas diretamente pela mineração. Esta reunião decorreu de um convite realizado pela Associação dos Docentes da Universidade Federal de Ouro Preto (ADUFOP) às demais entidades, especialmente àquelas que tem atuação direta na mineração extrativista nesta região em que esta seção sindical do ANDES/SN possui base e atuação.

A realização deste convite pela ADUFOP foi fortemente impulsionada a ocorrer naquele momento devido a realidade vivenciada na região do quadrilátero ferrífero em relação à pandemia da COVID-19, às suas primeiras manifestações mais agravadas e ao descaso por parte das mineradoras e dos poderes públicos municipais no sentido de enfrentarem a situação com a devida responsabilidade e compromisso ético que requeria. Aos trabalhadores diretamente vinculados à atividade produtiva da mineração, e consequentemente às suas famílias e à comunidade em geral, o cenário vivenciado era de exposição aos riscos de contaminação pela COVID-19. As mineradoras da região, desconsideravam qualquer medida de proteção aos trabalhadores no sentido de garantir o direito ao isolamento social. A atividade laboral nos complexos produtivos ocorria normalmente, desconsiderando o cenário de agravamento da pandemia na região4 ${ }^{4}$ sendo que já no dia 01 de abril de 2020 o município de Mariana-MG anunciava o primeiro óbito decorrente da COVID-19. Tal cenário impulsionou a elaboração e publicização de uma Nota Unificada: Paralisar a mineração por nossas vidas..$^{5}$ e precisava, na avaliação da ADUFOP, ganhar maior enraizamento a partir da articulação que já existia entre as entidades e movimentos sociais. 
Também, o convite ao diálogo e potencialização das articulações decorre do entendimento assumido pela então diretoria da entidade, de que é necessário pautar as questões que conformam o território de atuação da ADUFOP, para então conseguir pautar os impactos e as incidências de tais questões no âmbito da educação superior pública e da universidade, e assim travar as lutas a que a entidade/diretoria se propõe juntamente à sua base, assumindo uma perspectiva classista de atuação e articulação com os e as docentes sindicalizadas e com as demais entidades sindicais e movimentos sociais da região, e assim potencializando a referência de atuação em defesa da educação e da universidade pública, dos direitos da categoria docente e dos direitos da classe trabalhadora em seu conjunto.

Uma destacada ação nesse sentido foi a realização coletiva de evento intitulado $A$ MINERAÇÃO QUE QUEREMOS6 - I Encontro Regional Por um Novo Modelo de Mineração - I Jornada Universitária de Debates na Mineraşão ${ }^{7}$, no mês de novembro de 2019. Ação esta, fortemente reivindicada pelas entidades organizadoras e que, conforme é explicitado no documento final ${ }^{8}$ do evento, precisava ganhar cada vez mais enraizamento e organicidade na região. Reconhecendo o difićlimo contexto da mineração em tempos de pandemia ao que se refere ao descaso com a vida dos trabalhadores, seus familiares e com a comunidade em geral, e as articulações que já ocorriam entre as entidades na região, é que o convite se tornou pertinente e ocorreu. Destacamos alguns trechos deste convite à primeira reunião para uma maior articulação entre as entidades que posteriormente configurarão a FLAMa

\begin{abstract}
A ADUFOP, vem por meio deste, convidar sua entidade para um diálogo, aproximação entre movimentos sociais e sindicais que pautam e atuam na questão da mineração na região. [...] Consideramos que o documento final, resultado do Encontro $A$ MINERACCAO QUE QUEREMOS - I Encontro Regional Por um Novo Modelo de Mineração - I Jornada Universitária de Debates na Mineração, ocorrido em 06 de novembro de 2019, poderia ser tomado como um ponto de partida do diálogo proposto neste momento, pois foi construído por nós, por um conjunto de sujeitos, entidades e movimentos que construíram a ação. Além deste documento, ouvir e conhecer o que cada entidade está realizando nestes tempos de pandemia. (ADUFOP, 2020).
\end{abstract}

Esta primeira reunião contou com a participação de 23 pessoas que representaram 18 entidades, dentre as quais destacamos a presença de sindicatos do âmbito da educação (ADUFOP e SINASEFEIMFG), centrais sindicais (CSP-Conlutas e Intersindical - Central da Classe Trabalhadora), entidades religiosas vinculadas à Igreja Católica, movimento estudantil, sindicato vinculado diretamente na questão da mineração (Sindicato Metabase Inconfidentes), movimentos sociais (MAM e MAB), representantes moradoras/es atingidas/os de Itabira-MG e de Antônio Pereira- distrito de Ouro Preto-MG, partidos políticos do campo da esquerda, dentre outras entidades e organizações. Foi um encontro proveitoso, com manifestação da grande maioria dos presentes, e como síntese foi confirmado o entendimento de necessidade de potencializar ainda mais a articulação entre as entidades, especialmente, considerando o cenário de primeiros meses da pandemia da COVID-19 que se vivenciava à época, e as implicâncias desse cenário extremamente exigente no cotidiano e vida dos trabalhadores vinculados a essa atividade produtiva e às comunidades do entorno das minas e barragens. Como encaminhamentos dessa primeira reunião destacamos: a sugestão de realização de campanhas de solidariedade; a elaboração de uma nota- 
denúncia sobre o contexto da pandemia e a não paralização do trabalho na mineração; e o agendamento de uma próxima reunião na semana seguinte, precisamente no dia 21 de maio de 2020.

Ao longo do ano de 2020 aconteceram 12 reuniões. A média de participação das entidades e seus representantes se manteve estável até o mês de agosto, após, foi observado uma diminuição no número de participantes nas reuniões que ocorreram com uma periodicidade quinzenal. Considerando o contexto vivenciado à época, podemos destacar algumas questões que podem ter influenciado nas ausências nas reuniões: mudança de endereço e desligamento do vínculo com a entidade que compunha; conflito de agendas e compromissos; o cenário de eleições municipais vivenciado no mês de novembro que demandou a presença e maior dedicação por parte de algumas lideranças e organizações partidárias que vinham participando ativamente das reuniões; o cansaço decorrente da pandemia e do fato das reuniões estarem remetidas ao ambiente virtual, e somado a isso, a dificuldade de acesso à internet; as expressivas demandas que as entidades sindicais e movimentos sociais possuem, bem como, o reduzido número de militantes atuando na região; dentre outros aspectos.

No entanto, ressalta-se que não houve ao longo desse primeiro ano de conformação da FLAMa, pedido oficial de retirada do nome de nenhuma entidade que compunha a Frente desde o seu surgimento em maio de $2020^{\circ}$. Destacamos também que, por mais que algumas ausências ocorreram, ao longo dos meses aconteceu uma expressiva procura por maiores informações acerca da Frente, e estes representantes de movimentos sociais, de grupos de atingidos e atingidas diretamente, de partidos políticos do campo da esquerda, pesquisadores/docentes de diferentes áreas do conhecimento foram recebidos e incluídos nos canais que a FLAMa utiliza para diálogo e comunicação entre seus participantes, além das reuniões.

Em síntese ao acima exposto, a FLAMa, que foi se constituindo nessa frente ampla de diálogo e articulação das lutas e resistências à mineração extrativista, precisou considerar as especificidades de um contexto pandêmico que se apresentou e continua se apresentando cada vez mais agravado ao longo dos meses, ou seja, precisou criar mecanismos para seu funcionamento e organicidade para além da imprescindível presença física de seus membros, o que seria possível caso não estivéssemos vivenciando uma pandemia.

Foi na sétima reunião, realizada no dia 06 de agosto de 2020, que os e as participantes da Frente debateram mais fortemente a definição de um nome para a constituição-organização coletiva que estava se consolidando ao longo dos últimos 03 meses. Foi neste momento também, que ocorreu a definição do nome da Frente, isto é, através de um processo dialógico e que compreendeu os anseios e entendimentos das entidades acerca do que se propunha a partir dessa, e com essa, articulação ampla, se definiu e passou a ser utilizada a nomenclatura Frente de Luta dos Atingidos e Atingidas pela Mineração em Minas Gerais (FLAMa). Ainda, é neste momento de amadurecimento coletivo, que se explicita e se consolida a pertinência da criação de perfil da FLAMa nas redes sociais, a fim de tornar a Frente mais amplamente conhecida, e, para utilizar tais canais como meios para a realização das denúncias e de divulgação das lutas travadas. 
Ao observar as pautas das reuniões ao longo do ano de 2020 podemos observar que aconteceram intensos debates, a proposição e a realização de ações de solidariedade, especialmente as que visavam a doação de alimentos, máscaras e álcool em gel aos trabalhadores vinculados à mineração e aos moradores atingidos pelo rompimento da barragem de Fundão, e moradores do distrito de Antônio Pereira/Ouro Preto. Além disso, se observa que um mecanismo fortemente utilizado e realizado via FLAMa foi a elaboração e divulgação de notas de denúncia, notas de alerta, notas de preocupação, notas técnicas que foram remetidas aos poderes públicos municipais, ao Ministério Público, às instâncias de fiscalização e proteção ao Meio Ambiente, dentre outras instâncias e setores, e todas foram amplamente divulgadas via redes sociais da Frente ${ }^{10}$, obtendo um expressivo alcance de leitores.

Outro relevante momento de constituição e consolidação da FLAMa, de enraizamento e explicitação das lutas assumidas pela Frente, foi a realização, nos dias 16, 17 e 18 de novembro de 2020, da segunda edição do evento A Mineração Que Queremos, que compreendeu o II Encontro regional por um novo modelo de mineração e a II Jornada universitária de debates na mineração. Nestes espaços de debates, denúncias e reivindicações foram pautadas questões, tais como: Pandemia e Mineração - Saúde dos trabalhadores e saúde dos atingidos ${ }^{11}$; Barragem do Doutor - Impactos socioambientais no território ${ }^{12}$; Economia, educação, Trabalho e emprego - Por um novo modelo de mineração ${ }^{13}$, e no dia 19 de novembro foi construída e tornada pública a Carta Final ${ }^{14}$ em que foram expostas algumas considerações e proposições para as lutas vindouras.

Findando o ano de 2020, na $12^{a}$ reunião da Frente, ocorrida no dia 11 de dezembro, um dos pontos de pauta foi a avaliação do percurso e ações da FLAMa ao longo do ano. Este ponto teve a manifestação de 05 participantes ${ }^{15}$ e foi unânime a consideração de que o ano foi exitoso no sentido de conformação, consolidação e realização de ações pela Frente. Também, foi sinalizado acerca do desafio que foi realizar ações e articulações prioritariamente via internet ${ }^{16}$, considerando que o isolamento social foi uma premissa assumida para salvaguardar a vidas dos participantes.

Ainda, foi apontada como exitosa a realização do evento que aconteceu ao longo de 04 dias consecutivos e em formato remoto. Nesse sentido, foi sinalizado sobre o positivo e amplo alcance e interação que os debates realizados em formatos de lives obtiveram com o público, especialmente atingidos e atingidas de outras regiões do estado de Minas Gerais e do país, o que contribuiu para aproximar e potencializar as lutas, uma vez que, a realidade de violências e violações sofridas nos diferentes territórios é muito semelhante. Nessa referência, outro elemento fortemente enfatizado foi o desafio e a necessidade de a FLAMa alcançar e abranger outros territórios atingidos pela mineração no estado. Foram citados, os municípios de Catas Altas, Barra Longa, Itabira, Congonhas, Itabirito, Ouro Preto e neste, distritos como Miguel Burnier, por exemplo. Objetivando a ampliação de participantes/entidades e da atuação da Frente, foi proposto que em 2021 fossem realizadas lives a cada 02 meses, assim, se poderia fomentar a aproximação entre os territórios e comunidades atingidas, bem como, potencializar o caráter das denúncias acerca do modos operandi das mineradoras na região. 
Importa ressaltar que a mudança de ano não trouxe consigo uma melhoria nas condições de trabalho na mineração extrativista em contexto da pandemia, pelo contrário, com o passar dos meses a situação foi se agravando e confirmando as denúncias realizadas pela Frente em relação ao descaso com a vida dos trabalhadores e moradores das regiões/municípios minerados no quadrilátero ferrífero de Minas Gerais. Em 2021, a primeira reunião da FLAMa aconteceu no dia 29 de janeiro, e até o momento em que este texto é escrito, início de junho, a Frente já realizou 06 reuniões, sendo que a $7^{a}$ já está agendada para o dia 25 de junho.

As pautas perpassaram questões recorrentemente presentes e debatidas ao longo de 2020, além de situações que foram se configurando como urgentes de serem debatidas e enfrentadas coletivamente a partir das ações protagonizadas pelas mineradoras já nos primeiros dias do ano, tais como: Remoções em Antônio Pereira e em Barrão de Cocais, o contexto de reparação ao longo da bacia do Rio Doce, a morosidade dos trâmites judiciais - especialmente o de efetivação das assessorias técnicas aos atingidos e atingidas de Antônio Pereira, o contexto de descomissionamento de barragem em Itabira e audiência pública e mobilizações travadas pelo Comitê Popular dos Atingidos daquele município, a criminalização sobre as mulheres atingidas/lutadoras sociais, o cenário de alinhamento político de instituições públicas de ensino da região às mineradoras, dentre outras pautas. Os encaminhamentos e desafios sinalizados ao final de 2020 acerca da atuação, ampliação e consolidação das ações da FLAMa se relacionam diretamente com as pautas debatidas nestas reuniões do primeiro semestre de 2021, bem como, tiveram desdobramentos e aprofundamento com os debates protagonizados nas lives.

Destacamos que já nos primeiros dias de 2021, os e as atingidas do distrito de Antônio Pereira realizaram duas manifestações a fim de denunciar o descaso das mineradoras com a comunidade local.

Desde abril do ano passado, com o aumento do nível de emergência da Barragem Doutor, moradores do distrito sofrem com a situação. Insegurança, poluição, ausência de diálogo e de transparência nos critérios sobre quem deve ou não ser removido das casas em função da zona de auto salvamento (ZAS). Em relação às manifestações, os atingidos querem a imediata remoção das mais de 25 famílias que ainda residem sobre a mancha da Barragem Doutor; a contratação de uma assessoria técnica e a melhoria do diálogo entre a mineradora e a comunidade (PEREIRA, 2021).

No dia 12 de janeiro fecharam, por cerca de 09 horas, a via que dá acesso às minas Timbopeba, Alegria e Fazendão. No dia 13, repetiram a ação de trancamento da via, mas o cerceamento policial que foi expressivo e a posição criminalizante sobre o movimento impediram o fechamento da via e uma ação mais continuada por parte dos e das manifestantes. Esse fato traz à tona a violência e criminalização a que os movimentos sociais são cotidianamente submetidos, evidencia a opressão e a criminalização prioritariamente sobre a mulher atingida-lutadora social e explicita que o contexto relacional entre as mineradoras e as comunidades se dá a partir de trâmites morosos e que não cumprem o determinado pelo poder judicial, conforme pode ser evidenciado a partir da fala de mulheres atingidas que protagonizaram as manifestações.

Quem acaba sendo mais atingida nessa situação são as mulheres, as donas de casa. Somos nós que ficamos em casa com nossos filhos durante boa parte do dia, quem cuidamos da casa, da família. [...] 
O risco é pra todo mundo, não importa tanto se a mancha está localizada exatamente sobre a casa da gente ou não, a lama pode pegar a gente quando estivermos atravessando uma rua, como eu vou correr grávida? A Vale não está nem aí pra gente, a vida da gente infelizmente não vale nada. [...]

A juíza deu cinco dias para a Vale dizer o que seria feito com as famílias que ainda moram na ZAS. Esse prazo venceu no dia 22 de dezembro e até hoje a Vale não nos disse o que vai ser feito. Marcaram uma reunião ontem com a comunidade e não compareceram, pediram pra gente aguardar até dia 20 e com isso eles vão empurrando com a barriga e ganhando tempo, enquanto isso a gente fica nessa insegurança (PEREIRA, 2021).

Este acontecimento retrata o modos operandi das mineradoras na região. Diante dos relatos trazidos pelas mulheres atingidas de Antônio Pereira deliberou-se que o tema da primeira live do ano, que ocorreu no dia 25 de fevereiro, trataria sobre as 'Remoções forçadas das comunidades de Socorro e Antônio Pereira'17. Articulado a esse tema, a segunda live do ano abordou acerca do 'Novo processo indenizatório e a repactuação na bacia do Rio Doce: aspectos e desafios' ${ }^{18}$. Ambos os momentos foram de aproximação das comunidades atingidas e potencialização das lutas. Contaram com um público expressivo que interagiu a denunciou as mineradoras através de comentários no chat da exibição.

Além desses debates e potencialização das lutas via reuniões e lives, a FLAMa emitiu nesse primeiro semestre 04 notas: de repúdio sobre a criminalização das lutas sociais e sobre as mulheres lutadoras em territórios minerados; de alerta sobre tentativa da Vale e da prefeitura de Ouro Preto praticarem terrorismo de barragens com crianças e adolescentes de Antônio Pereira; de alerta sobre a redução do nível de risco da Barragem Doutor; e de repúdio ao evento $1^{\text {a }}$ SEMANA DO MEIO AMBIENTE - "SUSTENTABILIDADE: PERSPECTIVAS AGENDA DE 2030" promovido pelo Programa de pós-graduação em Sustentabilidade Socioeconômica Ambiental da UFOP, em parceria com a Fundação do Meio Ambiente (FEAM).

Convém explicitar que a nota de repúdio à criminalização das lutas e sobre as mulheres lutadoras sociais foi emitida considerando o corrido cotidianamente sobre as lideranças, considerando a ação da polícia nas manifestações de interdição das vias no começo do mês de janeiro e considerando o dia 8 de março que tem na Região de Ouro Preto-MG e Mariana-MG uma potente articulação das mulheres, dos coletivos e movimentos feministas, sendo que a mobilização virtual desencadeada em 2021 já contou com a participação da FLAMa na organização. As notas acerca do terrorismo de barragem e da redução do nível de risco da barragem Doutor se relacionam fortemente. Importa ressaltar que após a denúncia e mobilização contrária da comunidade, o ‘teatro de terrorismo de barragem’ às crianças foi cancelado, e após manifestações ocorridas na sequência, a Vale reduziu o nível da barragem, porém sem dar maiores explicações e orientações à população do distrito. Nesse bojo de atuação bastante questionável da mineradora, a constatação que fica é que é proposto e desenvolvido um conjunto de atividades cujo intuito maior é retardar a contratação de equipe de assessoria técnica à comunidade do distrito.

Somado a essas questões, evidenciamos que a terceira, e mais fortemente a quarta nota emitidas, de repúdio ao evento acadêmico realizado pela UFOP em parceria com a FEAM, deram-se no contexto 
de demonstrar e ao mesmo tempo repudiar o alinhamento teórico, político e interventivo que as instituições de ensino púbico da região possuem com as mineradoras. O contexto de alinhamento vem se explicitando cada vez mais, conforme foi denunciado e problematizado nas notas emitidas pela Frente.

Há algumas semanas, o distrito foi agraciado com o lançamento do projeto de extensão "UFOP e IFMG de Mãos Dadas Com o Pereira", uma iniciativa para aplicar a multa imposta pelo Ministério Público do Trabalho à Samarco (pertencente à Vale, obrigando-a a reconhecer Ouro Preto - e portanto, Antônio Pereira - como atingidos diretos pelo rompimento da Barragem de Fundão. Apesar de vários outros projetos contarem com a participação de professoras e professores tanto da UFOP quanto do IFMG, somente este mereceu atenção da Reitora da universidade, do diretor do IFMG campus Ouro Preto, do prefeito, e até - acreditem - da empresa criminosa, convidada de honra como "parceira" do projeto que só é necessário porque essa mesma empresa produziu o maior crime ambiental da história do Brasil (ADUFOP, 2021a).

Comporá a mesa/palestra de abertura do evento o Gerente Geral de Sustentabilidade na Samarco Mineração S/A. Perguntamos: que legitimidade tem para falar sobre "Gestão ambiental de Minas Gerais", alguém vinculado à mineradora responsável pelo rompimento criminoso da barragem de Fundão, de propriedade da Samarco, Vale e BHP Billiton, ocorrido em 05 de novembro de 2015 em Mariana-MG e que imediatamente matou 20 pessoas e destruiu, contaminou e matou modos de vida, a fauna e a flora por mais de $600 \mathrm{~km}$ até a lama/os rejeitos da barragem chegarem e adentrarem o mar no estado do Espírito Santo?

A programação do evento não conta com um representante sequer dos movimentos sociais que atuam na região em que a UFOP está inserida e que é o mesmo território completamente destruído pelo rompimento criminoso da barragem de Fundão. [...] A programação do evento não conta com a participação de nenhum atingido e/ou atingida pelo rompimento criminoso da barragem de Fundão, de propriedade da Samarco, Vale e BHP Billiton, ocorrido em 05 de novembro de 2015 em Mariana-MG, tampouco pessoas atingidas pelos recentes conflitos envolvendo a barragem de Doutor, da Vale em Antônio Pereira, ou da mina Gerdau, em Miguel Burnier; ou ainda, as famílias vítimas do processo de possessão mineral por parte da Pedreira Irmãos Machado, em Amarantina (ADUFOP, 2021b).

Tais posições assumidas no âmbito teórico inscrevem-se no âmbito político-interventivo das mineradoras e instituições de ensino, e tal âmbito político-interventivo pode assim ocorrer por assumir determinado referencial teórico, determinada visão e compreensão do mundo. Dessa forma, mais uma vez é possível perceber as conformações que a luta de classes assume na região, suas engrenagens e alinhamentos para a manutenção do status quo, tudo isso, sobre o cotidiano e vida das comunidades atingidas e sobre a natureza e meio ambiente. Marcas sangrentas de exploração, opressão, destruição ambiental e de morte que a região do quadrilátero ferrífero porta historicamente, e que cotidianamente é enfrentada por homens e mulheres que se organizam em variados sujeitos coletivos e que vislumbram uma outra organização societária, um outro modelo de mineração que possa efetivamente estar a serviço e atender as demandas do pleno desenvolvimento humano genérico e não os lucros de uma classe social, a burguesia e seus expoentes, tal qual ocorre sob os marcos do capitalismo.

Ressaltamos que a produção de conhecimento socialmente referenciado é fortemente impulsionada via FLAMa e, por meio dos e das estudantes, dos e das professoras e pesquisadoras que compõem a Frente as contribuições teóricas fomentam e orientam a atuação coletiva a partir de múltiplas áreas do conhecimento. Também compreendemos que não é unânime o posicionamento alinhado às mineradoras dentro das instituições de ensino. Reconhecemos as muitas, porém não hegemônicas, 
posições críticas e de denúncias que docentes, pesquisadores/as e discentes realizam sem suas ações pedagógicas de ensino, de pesquisa e de intervenção nas comunidades através da extensão. Nesse sentido, o chamado à luta, aos enfrentamentos às violências e violações causadas pelas mineradoras é cotidianamente realizado pelas entidades sindicais, movimentos sociais e movimento estudantil que compõem a FLAMa junto às comunidades acadêmicas da Universidade Federal de Ouro Preto, do Instituto Federal de Minas Gerais- Campus Ouro Preto, e das Escolas públicas da rede municipal e estadual da região. Destacamos que a partir do âmbito do ensino, da pesquisa e da extensão é possível desencadear ações e projetos que potencializem a ciência e a educação pública no sentido de alinhamento aos legítimos interesses das comunidades do território em que estas instituições de ensino se localizam e atuam.

Nessa mesma esteira, consideramos que as articulações e o diálogo entre os direta e indiretamente atingidos e atingidas da região são imprescindíveis, tanto quanto, é a articulação das pautas da mineração na região com as lutas mais amplas e gerais da classe trabalhadora. Nesse sentido, enfatizamos a participação da FLAMa na construção do 8M em Ouro Preto-MG, Mariana-MG e Região e a participação no Fórum Mineiro de Lutas, espaço que por meio de plenárias tem impulsionado as lutas no estado e os enfrentamentos à árdua conjuntura econômica e política que o país vivencia. Considerando tal construção e inserção nas lutas, referenciamos a importância de que as lutas contra a mineração extrativista assumam o caráter internacionalista. Ao atual estágio de mundialização do capital, de concentração e centralização da riqueza socialmente produzida, e aos ataques aos povos/classe trabalhadora e aos bens naturais comuns/à natureza nos mais longínquos territórios do globo, a resistência também precisa ser mundializada, ampla e abrangente.

\section{Considerações Finais}

Procuramos demonstrar nas linhas anteriores que a esfera da produção e a da reprodução social da vida, sob os marcos do capitalismo, possuem como fundamentos a propriedade privada dos meios de produção e a exploração da força de trabalho. Tais determinantes conformam a existência de classes sociais fundamentais e antagônicas, e desencadeiam o contexto da luta de classes, que ganha contornos bastante agravados nesse início de século XXI, especialmente no âmbito da mineração extrativista e de ofensivas e destruição ambiental.

Nessa conformação econômico-política e societária, o continente latino-americano é conformado a partir da condição de dependência e de superexploração da força de trabalho, o que implica ao seu território e às suas gentes um acirramento das condições de sobrevivência e uma ofensiva predatória aos bens naturais comuns.

A mineração extrativista na América Latina desencadeia o exaurimento e contaminação das águas, faz com que o solo perca suas funções básicas, é um fator de poluição ambiental de vapores, gases e rejeitos tóxicos, afeta a fauna e a flora do entorno dos complexos produtivos e das minas, dentre outros 
impactos negativos sobre o meio ambiente. Sobre as comunidades e populações a incidência se dá, além dos impactos decorrentes da degradação ambiental, através de chantagens, misoginia e machismo, racismo, perseguições e mortes/assassinatos de lideranças, de lutadores e lutadoras sociais que se põem no enfrentamento às engrenagens do atual modelo de mineração.

Esse contexto, de saqueio, destruição ambiental e mortes é secularmente vivenciado na América Latina. Também são seculares as lutas sociais e resistências travadas. Nesse sentido, a região do quadrilátero ferrífero de Minas Gerais ocupa um lugar emblemático na história. De território exaurido enquanto colônia, das marcas sangrentas da escravização de negros e negras, do trabalho forçado nas minas para a extração de ouro e outros metais, aos dias atuais, de mundialização da economia, de trabalho assalariado nas minas para a extração prioritariamente de minério de ferro, o que vemos é a perpetuação da apropriação desenfreada de bens naturais comuns e o descaso com a existência e vida humana. Os rompimentos criminosos das barragens de Fundão e do Córrego do Feijão são explicitações recentes desse contexto de barbárie cotidiana provocado pela mineração extrativista na região.

Diante de tais agravamentos, as comunidades se reafirmam enquanto sujeitos coletivos de luta e resistência. Um destes sujeitos coletivos é a FLAMa, que conforme procuramos demonstrar, tem um curto período de existência mas que já nasce muito fortalecida, pois se alimenta das lutas historicamente travadas na região, bem como, se potencializa a partir das articulações possíveis e necessárias entre atingidos e atingidas de diferentes territórios do estado de Minas Gerais, do país e do continente latinoamericano e se alimenta dos diferentes âmbitos de atuação das entidades sindicais, organizações, comitês e movimentos sociais que a compõe.

Assim, ao longo desse primeiro ano de existência a FLAMa pautou, refletiu, denunciou e articulou enfrentamentos via debates-lives, evento, reuniões, notas de repúdio, técnicas, de alerta, ações de solidariedade de classe, dentre outros mecanismos assumidos. A partir desse, e em decorrência desse acúmulo, alguns desafios se põem, dentre os quais destacamos: não se afastar da premissa que unifica a ação da Frente - o enfrentamento à mineração extrativista no estado de MG; manter e ampliar a organicidade entre as entidades que compõem a Frente; potencializar as reuniões através de ampla participação de representantes de diferentes sujeitos coletivos que se põem na luta contra a mineração extrativista; ampliar a troca de informações e o alcance dos debates para todas as regiões mineradas do estado de Minas Gerais; avançar no âmbito dos debates teóricos que fundamentam e subsidiam a atuação da Frente; assumir com clareza o papel e o âmbito de atuação da Frente, não confundindo-o com a atuação de equipes de assessorias técnicas; potencializar as lutas para que as comunidades atingidas tenham equipes de assessorias técnicas subsidiando e acompanhando as ações; não vincular-se financeiramente a entidades e empresas que propagam e desenvolvem destruição ambiental, especialmente através da mineração extrativista; potencializar a produção de conhecimento socialmente referenciado e este ser um aporte às comunidades e populações atingidas; acompanhar e denunciar os mecanismos de morosidade judicial em relação ao atendimento dos direitos dos atingidos e atingidas; acompanhar e denunciar as estratégias utilizada pelas mineradoras ao que se refere à morosidade do cumprimento das 
determinações legais, à perseguição às lideranças locais- especialmente às mulheres, à destruição ambiental, etc.; potencializar as ações de enfrentamento à mineração extrativista desenvolvidas por cada entidade que compõe a Frente, considerando suas especificidades de existência e atuação; potencializar a articulação e atuação da Frente nas lutas gerais da classe trabalhadora. Ressaltamos que tais desafios são próprios do processo de constituição e consolidação cada vez mais enraizado da FLAMa, e que tais questões já são amplamente debatidas nas reuniões e assumidas nos encaminhamentos e ações travadas pelas Frente.

O tempo histórico em que escrevemos estas linhas e reflexões é menos otimista que outros momentos. O acirramento da pandemia da COVID-19 sobre a classe trabalhadora em nosso país, a morte de mais de 500 mil pessoas representa um genocídio. O descaso governamental a um efetivo enfrentamento de ordem sanitária é uma marca dolorosa, que atingiu e atinge diretamente os trabalhadores vinculados à atividade produtiva da mineração extrativista e as comunidades locais. Um fator que impulsiona negativamente tal contexto é que a mineração foi considerada atividade essencial, e, portanto, tem amparo legal e normativo do governo federal para funcionar normalmente em meio a pandemia. Tais posições explicitam a posição assumida pelo Estado e seus representantes no contexto da luta de classes, e esta posição é estar ao lado das mineradoras. Diante de tal cenário, a realidade cotidiana tem demandado ações cada vez mais articuladas e com aderência social por parte dos movimentos sociais, entidades sindicais, comitês e associações dos diretamente atingidos pela mineração. Há muito por fazer, mas a cada dia, mais passos são dados pelos mineiros e mineiras, pelos atingidos e atingidas nesse caminho histórico de enfrentamentos, lutas e resistências à mineração extrativista na região do quadrilátero ferrífero, e a Flama inscreve-se neste contexto.

\section{Referências:}

ARTICULAÇÃO INTERNACIONAL DOS ATINGIDOS PELA VALE. Disponível em: https://atingidosvale.com/articulacao/quem-somos/. Acesso em: 08 jun. 2021.

ASSOCIAÇÃO DOS DOCENTES DA UNIVERSIDADE FEDERAL DE OURO PRETO (ADUFOP). Convite para reunião- pauta Mineração. 2020.

ASSOCIACÃO DOS DOCENTES DA UNIVERSIDADE FEDERAL DE OURO PRETO (ADUFOP Nota da FLAMa sobre a redução do nível de risco da Barragem Doutor. Disponível em: https://www.adufop.org.br/post/nota-da-flama-sobre-a-redu $\% \mathrm{C} 3 \% \mathrm{~A} 7 \% \mathrm{C} 3 \% \mathrm{~A} 3 \mathrm{o}-\mathrm{do}$-n $\% \mathrm{C} 3 \% \mathrm{ADvel}-$ de-risco-da-barragem-doutor. Acesso em: 14 de jun. 2021.

ASSOCIAÇÃO DOS DOCENTES DA UNIVERSIDADE FEDERAL DE OURO PRETO (ADUFOP Nota de repúdio da FLAMa-MG. Disponível em: https://www.adufop.org.br/post/nota-derep $\%$ C3\%BAdio-da-flama-mg. Acesso em: 14 de jun. 2021.

BARBOSA, Marcelo Bruno Ribeiro; ABREU, Sara; SIQUEIRA, Luiz Paulo Guimarães. Relatório Final Direitos Humanos e Mineração: Testemunho da Insustentabilidade. Disponível em: https://atingidosvale.com/wp-content/uploads/2020/11/Insustentabilidade 2015.pdf. Acesso em 10 jun. 2021.

BERTOLLO, Kathiuça. Mineração e superexploração da força de trabalho: análise a partir da realidade de Mariana-MG. 2017. Beatriz Augusto de Paiva. 185 p. Tese (doutorado) - Universidade Federal de Santa Catarina, Programa de Pós-graduação em Serviço Social, Florianópolis, 2017. 
BERTOLLO, Kathiuça; NOGUEIRA, Rodrigo. Aportes críticos sobre a mineração extrativista em Minas Gerais e sua relação com a universidade pública. In: MOASSAB, Andréia; VERRISSÍMO, Céline (Orgs.). Ecologia e Sociedade na América Latina. Caderno Sesunila n.03, Foz do Iguaçu, 2020. Disponível em: https://issuu.com/cadernosesunila/docs/03. Acesso em: 04 jun. 2021.

CARVALHO, Laura Nazaré de. Análise da ação dos sindicatos dos trabalhadores da mineradora Vale S.A. na região sudeste brasileira. Textos \& Debates, Boa Vista, n.23, p. 91-114, jan./jun. 2013. Disponível em: https://revista.ufrr.br/textosedebates/article/view/1623. Acesso em: 08 jun. 2021.

COELHO, Tádzio Peters; ANDRADE, Maria Júlia Gomes, SIQUEIRA, Luiz Paulo Guimarães; FREITAS, Marta de; ANDRADE, Lourival. O poder e a resistência dos movimentos populares e as alternativas ao modelo mineral brasileiro. In: ALVES, Murilo da Silva et al. (orgs). Mineração: realidades e resistências. 1.ed., São Paulo: Expressão popular, 2020, p.103 - 130.

ESPINOZA, Manuel Ignacio Martínez. Radiografía democrática del extractivismo minero en América Latina. Geopolítica(s) Revista de estudios sobre espacio y poder. Espanha, v.9 n. 1, 2018 a. Disponível em: https://revistas.ucm.es/index.php/GEOP/article/view/54914. Acesso em 29 jan. 2021.

ESPINOZA, Manuel Ignacio Martínez. Repertorios de acción colectiva frente al extractivismo minero en América Latina. Andamios, México, v. 15, n. 37, 2018b. Disponível em: Repertorios de acción colectiva frente al extractivismo minero en América Latina (scielo.org.mx). Acesso em: 29 jan. 2021.

GALEANO, Eduardo. As Veias Abertas da América Latina. Tradução de Galeano de Freitas. Rio de Janeiro: Paz e Terra, (estudos latino-americanos, v.12.), 44 edição, 2004.

GEOPARK QUADRILÁTERO FERRÍFERO. Localização. 2021. Disponível em: <http:/ /www.geoparkquadrilatero.org/?pg=geopark\&id=162>. Acesso em: 10 jun. 2021.

MARINI, Ruy Mauro. Dialética da Dependência. In: TRASPADINI, Roberta; STEDILE, João P. (Org.). Ruy Mauro Marini: vida e obra. São Paulo: Expressão Popular, 2005. p. 137-180.

MARX, Karl. O Capital: Crítica da economia política. Livro I. O processo de produção do capital. São Paulo: Boitempo, 2013.

MARX, Karl. O 18 de brumário de Luís Bonaparte. Tradução e notas Nélio Schneider; prólogo Herbert Marcuse. São Paulo: Boitempo, 2011.

MARX, Karl; ENGELS, Friedrich. Manifesto do Partido Comunista. 1. ed. São Paulo: Expressão Popular, 2008.

OLIVEIRA, Natália. Minas já sofreu com outros rompimentos de barragens. Disponível em: https://www.otempo.com.br/cidades/minas-ja-sofreu-com-outros-rompimentos-de-barragens-

1.1159501. Acesso em: 10 jun. 2021.

OSÓRIO, Jaime. Dependência e superexploração. In: SADER, Emir; DOS SANTOS, Theotônio (coord.). MARTINS, Carlos E.; VALENCIA, Adrian Sotelo (org.) A América Latina e os desafios da globalização: ensaios dedicados a Ruy Mauro Marini. Rio de Janeiro: Ed. PUC-Rio; São Paulo: Boitempo, 2009. p. 167-188.

OSÓRIO, Jaime. As classes Sociais no capitalismo. In: O Estado no centro da mundialização: A sociedade civil e o tema do poder. 1. ed. São Paulo: Outras expressões, 2014. p. 109-142.

PEREIRA, Lui. Pelo segundo dia consecutivo, moradores de Antônio Pereira protestam na MG129. Disponível em: https://www.agenciaprimaz.com.br/2021/01/13/pelo-segundo-dia-consecutivomoradores-de-antonio-pereira-protestam-na-mg-

129/?fbclid=IwAR3a7mc5IWFCsKEMBcttS1HyKv 1q95cJMz7zHxULLXkDJSUzme-5IVBwnc. Acesso em: 14 jun. 2021.

PRADO FILHO, José Francisco do; SOUZA, Marcelo Pereira. de. O licenciamento ambiental da mineração no quadrilátero ferrífero de minas gerais: uma análise da implementação de medidas de controle ambiental formuladas em eias/rimas. Engenharia Sanitária Ambiental, Rio de Janeiro, v. 9, n. 4, p.343-349, out./dez. $2004 . \quad$ Disponível em: 
<http://www.scielo.br/scielo.php?script=sci_arttext\&pid=S1413-41522004000400012>. Acesso em: 10 jun. 2021.

ROESER, Hubert M. P; ROESER, Patrícia A. O Quadrilátero Ferrífero-MG, Brasil: aspectos sobre sua história, seus recursos minerais e problemas ambientais relacionados. Geonomos, v. 18, n. 1, p.33-37, 2010. Disponível em: <http://igc.ufmg.br/geonomos/PDFs/1.06_Hubertetal_33_37.pdf>. Acesso em: 10 jun. 2021.

SEOANE, José; ALGRANATI, Clara. El sabor amargo del crescimento económico: la expansión del modelo extractivo entre 2003 y 2008. In: Extractivismo, despojo y crisis climática: desafíos para los movimientos sociales y los proyectos emancipatórios de Nuestra América. SEOANE, José; TADDEI, Emilio; ALGRANATI, Clara (orgs). 1 ed. Buenos Aires: Herramienta, El Colectivo, 2013, p. 61-82.

TEIXEIRA, Bruno. As condições laborais na mineração extrativista no quadrilátero ferrífero de Minas Gerais. In: Aula da disciplina Trabalho e Sociabilidade e disciplina Classes e Movimentos Sociais. Mariana-MG, 2021.

UNIVERSIDADE FEDERAL DE OURO PRETO (UFOP). Quadrilátero ferrífero 2050. Disponível em: https://qfe2050.ufop.br/municiipios-do-qfe. Acesso em: 10 jun. 2021.

XAVIER, Juliana Benício; VIEIRA, Larissa Pirchiner de Oliveira. O trabalho e seus sentidos: a destruição da força humana que trabalha. In: MILANEZ, Bruno; LOSEKANN, Cristiana. Desastre no Vale do Rio Doce: antecedentes, impactos e ações sobre a destruição. Rio de Janeiro: Folio Digital; Letra e Imagem, 2016. p. 197-232.

ZONTA, Marcio. Passar “dez anos sem férias” é condição comum na mineração brasileira, diz sindicato: terceirização alcança $50 \%$ da categoria, deixando os empregados desassistidos, segundo dados da Frente Sindical Mineral. Brasil de Fato, 04 jul. 2016. Disponível em: https://www.brasildefato.com.br/2016/07/04/passar-dez-anos-sem-ferias-e-condicao-comum-namineracao-brasileira-diz-sindicato/. Acesso em: 23 mai. 2021.

\section{Notas}

\footnotetext{
${ }^{1}$ Mestre e Doutora em Serviço Social pela Universidade Federal de Santa Catarina (UFSC). Professora do Departamento de Serviço Social da Universidade Federal de Ouro Preto (UFOP). É pesquisadora do Núcleo de Estudos, Pesquisa e Extensão Mineração do Outro, do Núcleo de Estudos e Pesquisas Trabalho e Questão Social na América Latina, do Grupo de Estudos e Pesquisa Trabalho e Política Social na América Latina e do Livre Hermana Núcleo de Estudos e Pesquisas sobre Formação Social Latino-Americana e Brasileira, vinculados ao CNPQ. Currículo Lattes: http://lattes.cnpq.br/3229587677691624. Orcid: http://orcid.org/0000-0003-2394-383X. E-mail: kathibertollo@gmail.com.

2 Ambos os municípios pertencem à Zona da Mata Mineira.

3 Para maiores informações da FLAMa, consultar as redes sociais: https://www.facebook.com/flamamg e https://www.instagram.com/flama $\mathrm{mg} /$.

${ }^{4} \mathrm{Um}$ preciso e relevante estudo sobre tal contexto está disponível em: $\underline{\text { Baixe aqui o relatório - Atingidos pela Vale }}$ (atingidosvale.com)

${ }^{5}$ Disponível em: NOTA UNIFICADA: PARALISAR A MINERAC C̃O POR NOSSAS VIDAS! (adufop.org.br).

${ }^{6}$ Maiores informações em: A MINERACC̃̃O QUE QUEREMOS (adufop.org.br)

7 Importa destacar que o chamado e a sinalização de importância acerca da realização da 'Jornada universitária de debates na mineração' decorrem de orientação coletiva e acúmulos advindos do V Encontro Nacional de Professores e Pesquisadores(as) na Mineração, ocorrido nos dias 6 e 7 de julho de 2019. Essa ação foi realizada em diferentes regiões e Universidades do país e foi se consolidando, sendo que no ano de 2020, apesar das adversidades trazidas pela pandemia, ocorreu novamente, no mês de novembro, uma série de Jornadas Universitárias que pautaram a mineração.

${ }^{8}$ Disponível em: Encontro debate um novo modelo de mineração (adufop.org.br)

${ }^{9}$ No dia 29 de setembro de 2020 aconteceu a live de lançamento da FLAMA. Nesta, é possível conhecer parte significativa das entidades que compõem a Frente. Disponível em: https://www.facebook.com/flamamg/videos/608926376449176

10 Todas as Notas emitidas pela FLAMa estão disponíveis em: @,FLAMA mg | Linktree.

${ }_{11}$ Disponível em: https://www.facebook.com/flamamg/videos/1052714805189457

12 Disponível em: https://www.facebook.com/flamamg/videos/3828548587155487

${ }_{13}$ Disponível em: https://www.facebook.com/flamamg/videos/3828548587155487
} 
14 Disponível em: https://www.adufop.org.br/post/a-minera\%C3\%A7\%C3\%A3o-que-queremos-carta-final

15 Importa ressaltar que esta reunião contou com a presença de 07 pessoas, sendo que esta foi a primeira reunião de um destes participantes.

16 As ações de solidariedade contaram com a participação presencial de alguns membros da FLAMa, no entanto, todos os cuidados sanitários foram tomados.

${ }_{17}$ Disponível em: https://www.facebook.com/649856995659964/videos/597592271198625

18 Disponível em: https://www.facebook.com/649856995659964/videos/564743194494550

Recebido em:16 de junho de.2021

Aprovado em: 19 de agosto de 2021 